\title{
Hospitals Plan to Start Their Own Generic Drug Company
}

The New York Times reports that groups representing more than 450 hospitals plan to form their own generic drug company (1). Intermountain Healthcare is leading the collaboration with several other large hospital groups, Ascension, SSM Health and Trinity Health, in consultation with the U.S. Department of Veterans Affairs, to form a not-for-profit drug company. The new firm is looking to create generic versions of about 20 existing drugs that the group says cost too much now or are in short supply. The article did not name the drugs targeted but expects the first of its pharmaceutical products to become available in 2019. Members of the consortium will contribute funds to finance the new drug company.

Richard A. Robbins, MD Editor, SWJPCC

\section{Reference}

1. Abelson R, Thomas K. Fed up with drug companies, hospitals decide to start their own. New York Times. January 18, 2018. Available at: https://www.nytimes.com/2018/01/18/health/drug-prices-hospitals.html (accessed 1/19/18). 